\title{
Interval training attenuates the metabolic disturbances in type 1 diabetes rat model
}

\author{
Treinamento intervalado atenua os distúrbios metabólicos \\ em modelo de ratos diabéticos do tipo 1
}

Ricelli Endrigo Ruppel Rocha', Isabela Coelho', Daniela Cristina T. Pequito', Adriana Yamagushi', Gina Borghetti', Ricardo Key Yamazaki', Gleisson Alisson Pereira de Brito', Juliano Machado', Marcelo Kryczyk', Everson Araújo Nunes², Graciela Venera ${ }^{3}$, Luiz Claudio Fernandes'

\author{
'Physiology Department, \\ Biological Science Sector, \\ Universidade Federal do Paraná \\ (UFPR), Curitiba, PR, Brazil \\ ${ }^{2}$ Physiological Sciences \\ Department, Biological Sciences \\ Center, Universidade Federal \\ de Santa Catarina (UFSC), \\ Florianópolis, SC, Brazil \\ ${ }^{3}$ Instituto Universitario Italiano \\ de Rosario; Institute of Chemical \\ and Physicochemical, Conicet, \\ Buenos Aires, Argentina
}

Correspondence to: Ricelli Endrigo Ruppel Rocha Rua Victor Baptista Adami, 919, ap. 102 89500-000 - Caçador, SC, Brasil ricelliendrigo@yahoo.com.br

Received on Aug/2/2012 Accepted on June/30/2013

\begin{abstract}
Objective: This study investigated the effect of interval training on blood biochemistry and immune parameters in type 1 diabetic rats. Materials and methods: Male Wistar rats were divided into four groups: sedentary ( $S E, n=15)$, interval training (IT, $n=17)$, diabetic sedentary ( $D S E, n=17)$, diabetic interval training (DIT, $\mathrm{n}=17$ ). Diabetes was induced by i.v. injection of streptozotocin $(60 \mathrm{mg} / \mathrm{kg}$ ). Swimming Interval Training consisted of 30-s exercise with 30-s rest, for 30 minutes, during 6 weeks, four times a week, with an overload of $15 \%$ of body mass. Plasma glucose, lactate, triacylglycerol and total cholesterol concentrations, phagocytic capacity, cationic vesicle content, and superoxide anion and hydrogen peroxide production by blood neutrophils and peritoneal macrophages were evaluated. Proliferation of mesenteric lymphocytes was also estimated. Results: Interval training resulted in attenuation of the resting hyperglycemic state and decreased blood lipids in the DIT group. Diabetes increased the functionality of blood neutrophils and peritoneal macrophages in the DSE group. Interval training increased all functionality parameters of peritoneal macrophages in the IT group. Interval training also led to a twofold increase in the proliferation of mesenteric lymphocytes after 6 weeks of exercise in the DIT group. Conclusion: Low-volume high-intensity physical exercise attenuates hyperglycemia and dislipidemia induced by type 1 diabetes, and induces changes in the functionality of innate and acquired immunity. Arq Bras Endocrinol Metab. 2013;57(8):594-602
\end{abstract}

\section{Keywords}

Interval training; diabetes mellitus; immune system; hyperglycemia

\section{RESUMO}

Objetivo: Este estudo investigou os efeitos do treinamento intervalado sobre parâmetros bioquímicos e imunológicos em ratos diabéticos do tipo 1. Materiais e métodos: Ratos Wistar machos foram divididos em quatro grupos: sedentário ( $S E, n=15)$, treinamento intervalado $(T I, n=17$, sedentário diabético (SED, $n=17$ ) e treinamento intervalado diabético (TID, $n=17)$. 0 diabetes foi induzido por uma injeção intravenosa de estreptozotocina $(60 \mathrm{mg} / \mathrm{kg}) .0$ treinamento intervalado de natação consistiu de 30s de exercício com 30s de recuperação, 30 minutos, durante 6 semanas, 4 vezes por semana, com sobrecarga de $15 \%$ da massa corporal. Foram avaliados glicemia, lactato sanguíneo, concentração de triacilglicerol e colesterol total, capacidade fagocítica, conteúdo de vesículas catiônicas, produção de ânion superóxido e peróxido de hidrogênio por neutrófilos sanguíneos e macrófagos peritoneais. A proliferação de linfócitos mesentéricos também foi avaliada. Resultados: 0 treinamento intervalado resultou em atenuação do estado hiperglicêmico e diminuiu os lipídeos sanguíneos no grupoTID. 0 diabetes aumentou a funcionalidade dos neutrófilos sanguíneos e macrófagos peritoneais do grupo SED. $O$ treinamento intervalado aumentou todos os parâmetros funcionais dos macrófagos peritoneais do grupo TI. O treinamento intervalado também aumentou duas vezes a proliferação dos linfócitos mesentéricos após seis semanas de exercício do grupo TID. Conclusão: 0 treinamento intervalado atenua a hiperglicemia e a dislipidemia induzida pelo diabetes do tipo 1 e induz mudanças na funcionalidade da imunidade inata e adquirida. Arq Bras Endocrinol Metab. 2013;57(8):594-602

\section{Descritores}

Treinamento intervalado; diabetes melito; sistema imune; hiperglicemia 


\section{INTRODUCTION}

$D$ iabetes mellitus (DM) is a group of metabolic disorders resulting from defects in insulin secretion, in insulin action or in both (1). Type 1 DM usually appears during childhood or adolescence and corresponds to $5 \%-10 \%$ of the diabetic individuals (2).

The presence of chronic hyperglycemia in individuals with type $1 \mathrm{DM}$ is associated with dyslipidemia, heart diseases, macrovascular and microvascular dysfunction, and increased susceptibility to infections. Therefore, intensification of glycemic improvement of lipid profile and immune cells function in patients with type 1 DM are essential features in reducing morbidity and mortality in this kind of population (3).

Currently, regular exercise, along with insulin therapy and meal planning, has been considered one of the three main approaches to the treatment of type I DM (4). The main benefits of exercise for people with type $1 \mathrm{DM}$ are: improvement of insulin sensitivity and lipid profile, reduction of insulin replacement, and attenuation of autonomic and cardiovascular dysfunction (5). Current recommendations of physical exercise for people with both types of DM are based in prescription of aerobic exercises, of moderate to vigorous intensity, or resistance exercises. Nevertheless, the adherence to the exercise program by the diabetic population is usually low by innumerous reasons, such as lack of time and motivation (6).

Recent studies have demonstrated that low-volume high-intensity interval training is more effective than traditional aerobic training in the metabolic adaptations and physical performance of individuals (7). Interval training could be a time-efficient strategy to achieve the same physiological benefits when compared with long duration continuous training. However, optimum dosage (intensity, duration, and recovery period) of the interval training protocol still needs to be established.

Our group and many researchers have used the DM experimental model induced by streptozotocin to investigate metabolic and immunologic alterations of DM. These animals exhibit many changes similar to those seen in humans with type $1 \mathrm{DM}$, such as hyperglycemia, dyslipidemia, and weight loss (8). We investigate here the effect of interval training, using low-volume and highintensity exercise, on blood biochemical and immune parameters in type 1 diabetic rats. We hypothesize that this protocol will improve some negative modifications caused by the type 1 DM status.

\section{MATERIALS AND METHODS}

\section{Animals}

All procedures involving animals were approved by the Local Committee of Animal Welfare at the Federal University of Paraná. Seven-days-old male Wistar rats were kept at constant temperature $\left(23 \pm 1^{\circ} \mathrm{C}\right)$, under a $12 \mathrm{~h}$ light/ $12 \mathrm{~h}$ dark cycle with free access to food and water. Animals were randomly divided into four groups: sedentary ( $\mathrm{SE}, \mathrm{n}=15$ ), interval training (IT, $\mathrm{n}=17)$, diabetic sedentary (DSE, $\mathrm{n}=17)$, diabetic interval training (DIT, $\mathrm{n}=17$ ).

\section{Enzymes and reagents}

Buffer reagents were obtained from Vetec Química Fina Ltda (Rio de Janeiro, RJ, Brazil). Streptozotocin (STZ) was purchased from Sigma Chemical Co (St Louis, MO, USA). Bioliquid line kits (Laborclin Laboratory Products Ltda., Pinhais, Paraná, Brazil) were used for the biochemical assays.

\section{Induction of diabetes}

The insulin deficiency state was induced by a single intravenous injection of freshly prepared $60 \mathrm{mg} / \mathrm{kg}$ of STZ dissolved in citrate buffer $(\mathrm{pH} 4.8)$, under ether anesthesia. The SE and IT groups received an equivalent volume of the buffer solution. Blood samples were obtained from the tail vein 48 hours after STZ administration. Animals with fasting blood glucose over 250 $\mathrm{mg} / \mathrm{dL}$ were considered in diabetic state $(9)$.

\section{Interval training protocol}

The interval training protocol was based on the model proposed by Braga and cols. (10), with minor modifications. The training was carried out in a swimming pool apparatus with temperature maintained between 30 and $32^{\circ} \mathrm{C}$. The apparatus was composed by two tubes with a fenestrated inner tube which enabled the animal to be kept in the water and to be removed at the end of the set. Initially, the animals performed l week of water adaptation (Monday, Wednesday, and Friday), swimming 15 minutes continuously with an overload of $6 \%$ of their body mass fastened to them through a vest. In the second week, the IT and DIT groups performed 30 -s exercise with 30-s rest during 6 weeks, four times a week, with an overload of $15 \%$ of their body mass fastened to them through a vest. Training sections were performed on Mondays, Tuesdays, Thursdays, and 
Fridays; all trained rats rested on the other days. The SE and DSE groups were submitted to the same transportation procedures and were kept in a shallow pool during the time the exercising groups were in their training. At the end of 6 weeks of training, rats from all groups were anesthetized and decapitated 72 -h after the last session of exercise in order to eliminate the acute effect of exercise on metabolism. Blood was collected to obtain plasma and cells by centrifugation. Resident peritoneal macrophages and blood polymorphonuclear cells were obtained for determination of phagocytic capacity, cationic vesicle content, and superoxide anion and hydrogen peroxide production.

\section{Biochemical parameters}

Blood lactate was determined by a portable lactate analyzer (model Accusport, Boehringer Mannheim $\mathrm{GmbH}, \mathrm{GER})$ to measure the intensity of interval training (11). The animals from IT and DIT groups were submitted to swimming exercise protocol. After $15 \mathrm{mi}-$ nutes of exercise, they were removed from the pool to collect a drop of blood from their tails for analysis. SE and DSE groups were kept in a shallow pool during the time when the other groups were in their training, and underwent the same blood lactate evaluation process, but did not exercise in the pool. Post-exercise blood lactate average in the IT and DIT groups was 10.33 $\pm 1.34 \mathrm{mmol} / \mathrm{dL}$ and $8.72 \pm 0.15 \mathrm{mmol} / \mathrm{dL}$, respectively, and in the SE and DSE groups was $2.67 \pm 0.23$ $\mathrm{mmol} / \mathrm{dL}$ and $3.13 \pm 0.13 \mathrm{mmol} / \mathrm{dL}$, respectively.

Plasma glucose, triacylglycerol and total cholesterol concentrations were measured using colorimetric enzymatic assays as described by Togni and cols. (12), $72 \mathrm{~h}$ after the last training section and after at least 12 $\mathrm{h}$ fast. The results are expressed as $\mathrm{mg} / \mathrm{dL}$.

\section{Macrophage isolation}

Resident macrophages were obtained by intraperitoneal lavage with $10 \mathrm{~mL}$ of sterile phosphate buffered saline (PBS). Peritoneal cells were collected by centrifugation $\left(290 \mathrm{~g}\right.$ at $4^{\circ} \mathrm{C}$ for $5 \mathrm{~min}$ ), washed, and resuspended in PBS or RPMI medium and counted in a Neubauer chamber by optical microscopy using a trypan blue solution (1\%); viability was $96 \%$. Peritoneal cells were characterized by flow cytometry; purity was about $50 \%$. Macrophages were further purified by incubating peritoneal cells in tissue culture plates for $2 \mathrm{~h}$ and washing them three times with PBS to remove non-adherent cells (13).

\section{Blood polymorphonuclear cells isolation}

Polymorphonuclear cells were isolated from the blood of rats. Blood $(10 \mathrm{~mL})$ was diluted with an equal volume of $\mathrm{PBS}$ at $\mathrm{pH} 7.4$ containing $100 \mathrm{mM} \mathrm{CaCl}_{2}^{-}$ $50 \mathrm{mM} \mathrm{MgCl}$ and carefully layered on $10 \mathrm{~mL}$ of a commercial gradient of Ficoll-Paque Plus (density = 1,077 ). The tube was centrifuged at $1,200 \mathrm{~g}$ at $18^{\circ} \mathrm{C}$ for $30 \mathrm{~min}$. The supernatant, rich in mononuclear cells, was discarded. The pellet was submitted to hypotonic treatment with $10 \mathrm{~mL}$ of solution containing 150 $\mathrm{mM} \mathrm{NH} 4 \mathrm{Cl}, 10 \mathrm{mM} \mathrm{NaHCO}$, and $0.1 \mathrm{mM}$ EDTA to promote lysis of contaminating erythrocytes. The sample was homogenized and maintained for $10 \mathrm{~min}$ at $37^{\circ} \mathrm{C}$ to allow erythrocyte lysis, and then centrifuged at $1,200 \mathrm{~g}$ at $4^{\circ} \mathrm{C}$ for $10 \mathrm{~min}$. Centrifugation was repeated twice. Polymorphonuclear cells were counted in a Neubauer chamber under optical microscope. The number of viable cells, always > 95\% neutrophils, was determined by trypan blue exclusion (14).

\section{Phagocytic capacity}

Aliquots of peritoneal macrophage or blood neutrophil suspension $(0.1 \mathrm{~mL})$ were added to the wells of a 96-well flat-bottomed tissue culture plate $\left(10^{5}\right.$ cells $/$ well) and left to adhere for $60 \mathrm{~min}$. Plates were washed twice with PBS to remove non-adherent cells. Then, $10 \mu \mathrm{l}$ of neutral-red stained zymosan ( $1 \times 10^{8}$ particles $/$ $\mathrm{mL}$ ) were added to each well. After incubation for 30 min, cells were fixed with Baker's formalin-calcium (4\% formaldehyde, $2 \%$ sodium chloride, $1 \%$ calcium acetate) for $30 \mathrm{~min}$. Afterwards, the cells were washed two times and centrifuged at $450 \mathrm{~g}$ for $5 \mathrm{~min}$. The neutral-red stain was solubilized by adding $0.1 \mathrm{~mL}$ of acidified alcohol ( $10 \%$ acetic acid, $40 \%$ ethanol in distilled water) to each well. After $30 \mathrm{~min}$, the absorbance of each well was read on a plate reader at $550 \mathrm{~nm}$. Phagocytosis was calculated from a standard curve drawn from known amounts of stained zymosan, and the results were expressed as percentage of the control (13).

\section{Cationic vesicle content}

The uptake of the cationic dye neutral red, which concentrates mostly in cell lysosomes, was used to assess the volume of the peritoneal macrophage or blood neutrophil lysosomal system. Peritoneal macrophage or blood neutrophil suspensions $(0.1 \mathrm{~mL})$ were added to the wells of a 96-well flat-bottomed tissue culture plate $\left(10^{5}\right.$ cells/well $)$ and left to adhere for $60 \mathrm{~min}$. Plates 
were washed twice with PBS to remove non-adherent cells. Twenty microliters of $3 \%$ neutral red in PBS were added to the adhered cells per well for $30 \mathrm{~min}$. The cells were then washed twice with PBS by centrifugation ( $450 \mathrm{~g}$ for $5 \mathrm{~min}$ ). Neutral red was solubilized by a 30 min incubation adding $0.1 \mathrm{~mL}$ of $10 \%$ acetic acid plus $40 \%$ ethanol solution. Absorbance was read at $\mathbf{5 5 0}$ $\mathrm{nm}$ and the cationic vesicle content is expressed as percentage of the control (13).

\section{Hydrogen peroxide production}

Hydrogen peroxide production by peritoneal macrophages or blood neutrophils was measured as described by Pizatto and cols. (15). This assay is based on the horseradish peroxidase (HRPO)-dependent conversion of phenol red into a colored compound by $\mathrm{H}_{2} \mathrm{O}_{2}$. After the $60 \mathrm{~min}$ of adhesion procedure and non-adherent cells washing, macrophages or neutrophils (final volume $0.1 \mathrm{~mL}$ ) were incubated in the presence of glucose ( $5 \mathrm{mM})$, phenol red solution $(0.56 \mathrm{mM})$, and HRPO $(8.5 \mathrm{U} / \mathrm{mL})$ in the dark for $\mathrm{l} \mathrm{h}$ at $20^{\circ} \mathrm{C}$. After this period, absorbance was measured at $620 \mathrm{~nm}$ on a plate reader. The concentration of $\mathrm{H}_{2} \mathrm{O}_{2}$ was determined from a standard curve prepared in parallel. $\mathrm{H}_{2} \mathrm{O}_{2}$ production is expressed as percentage of control (15).

\section{Superoxide anion production}

Superoxide anion production was estimated by the reduction of nitroblue tetrazolium (NBT) assay. Peritoneal macrophage or blood neutrophil suspensions $(0.1$ $\mathrm{mL}$ ) were added to the wells of a 96-well flat-bottomed tissue culture plate $\left(10^{5}\right.$ cells/well $)$ and left to adhere for $60 \mathrm{~min}$. Plates were washed twice with PBS to remove non-adherent cells. Peritoneal macrophages or blood neutrophils $(0.45 \mathrm{~mL})$ suspended in PBS were incubated for $1 \mathrm{~h}$ at $37^{\circ} \mathrm{C}$ in the presence of $0.1 \% \mathrm{NBT}$. The reaction was stopped by adding $0.45 \mathrm{ml}$ of acetic acid. Then, the mixture was centrifuged for $30 \mathrm{~s}$ at $2,500 \mathrm{~g}$. Reduction of NBT results in the formation of blue formazan, which was detected spectrophotometrically at $560 \mathrm{~nm}(15)$. The results are expressed as percentage of control.

\section{Lymphocyte proliferation}

Lymphocytes from gut-associated lymphoid tissues were isolated and cultured at $37^{\circ} \mathrm{C}$ in an $\mathrm{O}_{2}: \mathrm{CO}_{2}(19: 1)$ atmosphere in 96-well culture plates at a density of $2 \times 10^{5}$ cells/well and a total culture volume of $200 \mu \mathrm{L}$ in RPMI buffer supplemented with $2 \mathrm{mM}$ of glutamine, $10 \%$ fetal bovine serum, $0.1 \%$ antibiotics (streptomycin and penicillin) and $5 \mu \mathrm{g} / \mathrm{mL}$ of concanavalin A (Con-A). After $48 \mathrm{~h}$ of culture, $20 \mu \mathrm{L}$ of $\left[2-{ }^{14} \mathrm{C}\right]$-thymidine was added to each well $(0.01 \mu \mathrm{Ci} /$ well $)$, and cells were incubated for another $18 \mathrm{~h}$. Cells were then harvested onto glass fiber disks (Cox Scientific, Kettering, England) and washed in a Skatron Cell Harvester (Skatron Instruments AS, Lierbeyen, Norway). Radioactive thymidine incorporation into DNA was determined by liquid scintillation counting in a Beckman LS 6000IC scintillation counter (16). The results were expressed as index of proliferation, which was calculated as the ratio between the mean with stimulus (Con-A) and without stimulus.

\section{Statistical analysis}

The Shapiro-Wilk test was used to verify data normality per group, and the Levene test was used to analyze the homogeneity between group variances. Parametric statistics were employed for biochemical and immune parameters. Changes in body mass during six experimental weeks (pre- vs. post-training) were analyzed using Mann-Whitney test. Statistical analysis was performed by two-way analysis of variance using exercise and diabetes as independent factors. Post-hoc tests were Tukey's test corrected for multiple comparisons, and data were analyzed using the Graph Pad Prisma software, version 5.0. The results are presented as mean \pm SEM or mean and confidence interval $(\mathrm{CI})$. A value of $p<0.05$ indicates statistical significance.

\section{RESULTS}

\section{Total body mass}

Body mass (Table 1) from SE, IT, and DIT groups increased significantly after 6 weeks $(23.2,16.2$, and $4.7 \%$, respectively, $\mathrm{p}<0.01)$. On the other hand, the diabetic state reduced significantly the increase of body mass by $3.8 \%$ when compared to non-diabetic rats $(\mathrm{p}<0.0001)$.

\section{Blood biochemical parameters}

Interval training did not modify the fasting glycemia (Table 2) of the IT group when compared with the $\mathrm{SE}$ group $\left(70.45 \pm 2.89 \mathrm{mg} \cdot \mathrm{dL}^{-1}\right.$ and $78.5 \mathrm{l} \pm 2.73$ mg.dL ${ }^{-1}$, respectively, $\left.\mathrm{p}>0.05\right)$. The diabetic group (DSE) presented higher glycemia than the SE group $(p<0.0001)$. Exercise caused attenuation of the hyper- 
glycemic state in the DIT group when compared with the non-trained group $(\mathrm{p}<0.0001)$. Nevertheless, glycemia of the DIT group rats was higher than the IT group $(\mathrm{p}<0.0001)$. Triaclylglycerol serum levels were 1.4-fold lower in the IT group than in SE group ( $\mathrm{p}<$ $0.0001)$. Diabetic rats showed higher triacylglycerolemia $(2.0$-fold $)$ than the SE group $(\mathrm{p}<0.0001)$.

Interestingly, interval training caused a significant reduction (1.7-fold) in the triacylglycerolemia of diabetic rats (DIT), compared with sedentary diabetic rats $(\mathrm{p}<$ $0.0001)$ and reaching values similar to SE group.

Animals submitted to interval training also reduced total serum cholesterol (CO) levels when compared with sedentary rats $(\mathrm{p}<0.0001)$. Diabetic rats submitted to interval training decreased $\mathrm{CO}$ levels when compared with diabetic sedentary rats $(\mathrm{p}<0.0001)$, reaching levels similar to the IT group. Immune parameters from polymorphonuclear cells.

Phagocytic capacity, cationic vesicle content, and superoxide anion and hydrogen peroxide production by neutrophils were assayed in all experimental groups. After 6 weeks of interval training the phagocytic capacity of both the IT and SE group were the same (102.7 $\pm 4.96 \%$ and $100 \pm 5.21 \%$, respectively, $\mathrm{p}>0.05$ ). Diabetic condition increased the phagocytic capacity by $94 \%$ when compared with SE $(\mathrm{p}<0.0001)$ (Table 3 ). After the diabetic rats (DIT) finished the interval training, the phagocytic capacity did not change when compared with the DSE group ( $p>0.05$ ), but it was still $80 \%$ higher when compared with the IT group (p $<0.0001$ ) (Table 3).

There was no difference in cationic vesicle content between SE and IT groups $(100 \pm 2.56 \%$ and $95.10 \pm$ $10.78 \%$, respectively, $\mathrm{p}>0.05)$. The diabetic state induced a 1.4-fold increment in the cationic vesicle content compared with the SE group $(\mathrm{p}<0.0001)$. The interval training protocol reduced the cationic vesicle content by $58 \%$ in the diabetic rats when compared with the sedentary diabetic ones $(p<0.0001)$. There was no difference in this variable between the other groups $(\mathrm{p}>0.05)$ (Table 3$)$.

Table 1. Body mass $(\mathrm{g})$ pre- and post-training moments, and body mass relative variation $(\Delta \%)$ between those moments in sedentary (SE), interval training (IT), sedentary diabetic (DSE), and interval training diabetic (DIT) groups during six experimental weeks

\begin{tabular}{lllc}
\hline Group & Pre-training body mass $\mathbf{( g )}$ & Post-training body mass $\mathbf{( g )}$ & $\Delta \%$ \\
\hline SE & $292.1 \pm 8.8(272.9-311.4)$ & $360.1 \pm 12.0^{*}(334.1-386.2)$ & $23.2 \pm 1.7(19.49-27.0)$ \\
IT & $302.5 \pm 9.5(282.0-322.9)$ & $351.7 \pm 11.8^{*}(326.2-377.2)$ & $16.2 \pm 1.0^{\mathrm{b}}(14.0-18.4)$ \\
DSE & $231.4 \pm 7.0(216.5-246.4)$ & $237.7 \pm 10.6(215.1-260.3)$ & $3.8 \pm 5.5^{\mathrm{a}}(-8.0-15.7)$ \\
DIT & $247.8 \pm 7.5(232.2-263.5)$ & $260.4 \pm 10.3^{*}(238.9-281.9)$ & $4.7 \pm 1.7^{\mathrm{a}}(1.1-8.4)$ \\
\hline
\end{tabular}

Data are expressed as mean $\pm \mathrm{Cl}$ (confidence interval).

${ }^{*} \mathrm{P}<0.01$ compared with the group's pre-training body mass; ${ }^{\mathrm{P}} \mathrm{P}<0.0001$ compared with the SE group;

${ }^{\mathrm{b}} \mathrm{P}<0.0001$ compared with the DSE group.

Table 2. Serum glucose $\left(m g \cdot \mathrm{dL}^{-1}\right)$, triacylglycerol $\left(m g \cdot \mathrm{dL}^{-1}\right)$ and total cholesterol (mg. $\left.\mathrm{dL}^{-1}\right)$ concentrations from sedentary (SE), interval training (IT), sedentary diabetic (DSE), and interval training diabetic (DIT) groups at the end of 6 weeks of training

\begin{tabular}{lccc}
\hline Group & Glucose $\left.\mathbf{( m g . d L}{ }^{-1}\right)$ & Triacylglycerol (mg.dL-1) & Total cholesterol (mg.dL-1) \\
\hline SE & $78.51 \pm 2.7$ & $65.26 \pm 3.6$ & $77.56 \pm 2.6$ \\
IT & $70.45 \pm 2.8$ & $45.78 \pm 2.4^{\mathrm{a}}$ & $57.48 \pm 1.9^{\mathrm{a}}$ \\
DSE & $401.3 \pm 24.6^{\mathrm{a}}$ & $124.3 \pm 10.6^{\mathrm{a}}$ & $87.63 \pm 5.6$ \\
DIT & $318.1 \pm 10.9^{\mathrm{b}}$ & $71.35 \pm 4.0^{\mathrm{b}}$ & $51.96 \pm 1.8^{\mathrm{b}}$ \\
\hline
\end{tabular}

Data are expressed as mean \pm SEM.

${ }^{\text {a } P}<0.0001$ compared with the SE group; ${ }^{\mathrm{b} P}<0.0001$ compared with the DSE group.

Table 3. Blood neuthrophil phagocytic capacity, cationic vesicle content, superoxide anion, and hydrogen peroxide production in sedentary rats (SED), interval training (IT), sedentary diabetic (DSE), and interval training diabetic (DIT) rats

\begin{tabular}{lcccc}
\hline Group & Phagocytic capacity (\%) & Cationic vesicle content (\%) & Superoxide anion production (\%) & Hydrogen peroxide production (\%) \\
\hline SE & $100.0 \pm 5.2$ & $100.0 \pm 2.5$ & $100.0 \pm 3.9$ & $100.0 \pm 1.3$ \\
IT & $102.7 \pm 4.9$ & $95.10 \pm 10.7$ & $159.8 \pm 11.2^{\mathrm{a}}$ & $110.0 \pm 3.8$ \\
DSE & $194.2 \pm 10.8^{\mathrm{a}}$ & $237.7 \pm 10.5^{\mathrm{a}}$ & $169.8 \pm 8.7^{\mathrm{a}}$ & $131.8 \pm 11.0^{\mathrm{a}}$ \\
$\mathrm{OIT}$ & $182.7 \pm 10.5^{\mathrm{b}}$ & $114.5 \pm 5.9^{\mathrm{b}}$ & $169.4 \pm 14.6$ & $127.9 \pm 7.8$ \\
\hline
\end{tabular}

Data are expressed as mean \pm SEM.

${ }^{\text {a } P}<0.0002$ compared with the SE group; ${ }^{\mathrm{p} P}<0.0001$ compared with the DSE group. 
Interval training increased superoxide anion production by $59 \%$ in the IT compared with the SE group $(\mathrm{p}<0.0002)$. Diabetic state increased superoxide anion production by $69 \%$ in the DSE compared with the SE group $(\mathrm{p}<0.0001)$, and when diabetic rats finished the exercise, superoxide anion production by blood neutrophils was not modified compared with the DSE group ( $p>0.05)$. Between the IT and the DIT group, there was no difference in the production of this reactive oxygen species $(\mathrm{p}>0.05)$ (Table 3$)$.

Interval training did not modify hydrogen peroxide production in the non-diabetic group compared with SE ( $p>0.05)$. Diabetic condition increased the hydrogen peroxide production by $31 \%$ compared with the SE group $(\mathrm{p}<0.0001)$, and when diabetic rats finished the interval training, production was not different $(\mathrm{p}>0.05)$. There was no difference between IT and DIT groups, either $(\mathrm{p}>0.05)$ (Table 3$)$.

Phagocytic capacity, cationic vesicle content, and superoxide anion and hydrogen peroxide production by peritoneal macrophages are shown in the Table 4. After 6 weeks of interval training 4 times a week, phagocytosis by peritoneal macrophages increased 3.8fold in the IT group when compared with sedentary rats $(\mathrm{SE})(\mathrm{p}<0.0001)$. Diabetic rats without training (DSE) increased phagocytosis by 2.7-fold when compared with the SE group $(\mathrm{p}<0.0001)$. Diabetic rats submitted to interval training (DIT) increased phagocytosis by 1.6-fold when compared with diabetic rats (DIT vs. DSE, $\mathrm{p}<0.0001$ ). Phagocytosis by peritoneal macrophages was not different in the IT and DIT group $(\mathrm{p}>0.05)$ (Table 4).

Interval training group (IT) increased cationic vesicle content $94 \%$ when compared with the SE group $(\mathrm{p}<0.0001)$. Diabetic condition (DSE) also increased the cationic vesicle content by $91 \%$ when compared with the SE group $(\mathrm{p}<0.0001)$. When diabetic rats finished the interval training (DIT), cationic vesicle content did not change $(\mathrm{p}>0.05)$ (Table 4$)$.
The IT group increased superoxide anion production slightly when compared with the SE group $(\mathrm{p}<0.05)$. The diabetic state (DSE) also led to a slight increase in superoxide anion production when compared with SE ( $\mathrm{p}$ $<0.05)$. Superoxide anion production was not different between the DSE and DIT groups $(\mathrm{p}<0.05)$ (Table 4).

Hydrogen peroxide production increased $7.3 \%$ when compared with the SE group $(\mathrm{p}<0.0002)$ after 6 weeks of interval training (IT). Diabetes (DSE) increased hydrogen peroxide production by $6.9 \%$ when compared with the SE group $(\mathrm{p}<0.0002)$. The interval training did not alter hydrogen peroxide production of the DIT compared with the DSE group ( $\mathrm{p}>0.05$ ) (Table 4).

\section{Lymphocyte proliferation}

The proliferation index of gut-associated lymphocytes from the SE group was $6.25 \pm 0.54$. Interval training did not modify proliferation index in the non-diabetic group, compared with SE $(p>0.05)$. There was no change in the proliferation index in diabetes state when compared with sedentary animals $(\mathrm{p}>0.05)$. Diabetic rats trained for six weeks (DIT) had a twofold increase in the proliferation index compared with the DSE group $(\mathrm{p}<$ $0.0001)$. Between the IT and DIT groups, there was also significant difference in the proliferation index $(4.30 \pm$ 0.73 vs. $13.11 \pm 1.77$, respectively, $\mathrm{p}<0.05)$ (Figure 1).

\section{DISCUSSION}

In the last decades, several new methodologies of physical training were design to improve physical performance or promote health. The benefits of interval training aroused the interest of health professionals because the volume of exercise is substantially lower when compared with traditional aerobic training. Another important factor is that there is no consensus regarding the nature of the exercise and particularly the relationship between volume and intensity prescription in order to achieve positive adaptations for different diseases (17).

Table 4. Peritoneal macrophage phagocytic capacity, cationic vesicle content, superoxide anion, hydrogen peroxide production, and adhesion obtained from sedentary rats (SED), interval training (IT), sedentary diabetic (DSE), interval training diabetic (DIT) rats

\begin{tabular}{lcccc}
\hline Group & Phagocytic capacity (\%) & Cationic vesicle content (\%) & Superoxide anion production (\%) & Hydrogen peroxide production (\%) \\
\hline SE & $100.0 \pm 2.5$ & $100.0 \pm 3.2$ & $100.0 \pm 5.6$ & $100.0 \pm 1.6$ \\
IT & $379.4 \pm 31.1^{\mathrm{a}}$ & $194.1 \pm 3.3^{\mathrm{a}}$ & $196.8 \pm 4.4^{\mathrm{a}}$ & $107.3 \pm 0.9^{\mathrm{a}}$ \\
DSE & $271.0 \pm 22.04^{\mathrm{a}}$ & $191.6 \pm 15.3^{\mathrm{a}}$ & $197.2 \pm 8.3^{\mathrm{a}}$ & $106.9 \pm 1.2^{\mathrm{a}}$ \\
DIT & $432.5 \pm 21.3^{\mathrm{b}}$ & $190.6 \pm 15.6$ & $213.2 \pm 14.4$ & $105.5 \pm 1.2$ \\
\hline
\end{tabular}

Data are expressed as mean \pm SEM.

${ }^{\text {a } P}<0.0003$ compared with SE group; ${ }^{\mathrm{b} P}<0.0003$ compared with DSE group. 


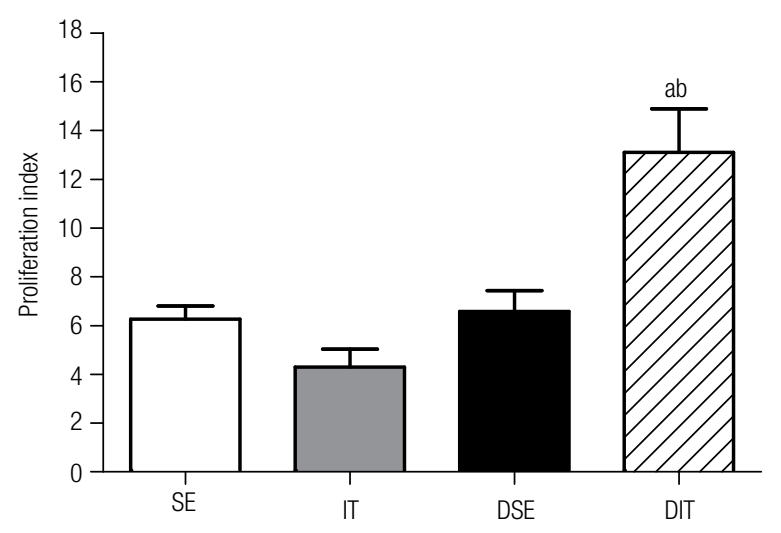

Figure 1. Proliferation index of gut-associated lymphocytes obtained from sedentary (SE), interval training (IT), sedentary diabetic (DSE), and interval training diabetic (DIT) groups. Values are expressed as mean \pm SEM.

${ }^{\text {a } P}<0.0001$ compared with the DSE group; ${ }^{\text {b } P}<0.0001$ compared with the IT group.

All levels of exercise can be performed by people with type $1 \mathrm{DM}$, provided complications are not present and patients have good glycemic control (18). It is essential to adjust the treatment (insulin, diet and exercise) to avoid hypoglycemia during exercise or many hours after exercise. Interval training is classified as high intensity exercise and energy expenditure is also high. Thus, metabolic control before exercise, blood glucose before and after exercise, and food intake must be controlled and adapted.

Our results in this STZ-induced diabetes model showed body mass loss, and the training protocol did not alter body mass reduction caused by the diabetic state (Table 1). It has been demonstrated that rats treated with STZ to induce type I DM possess a compromised ability for normal skeletal muscle growth and impaired body weight gain $(19,20)$. Krause and cols. (21) showed in their research that eight weeks of diabetes streptozotocin-treated rats $(120 \mathrm{mg} / \mathrm{kg})$ resulted in significantly less body mass, less absolute muscle mass, and less epididymal fat mass compared with control rats.

The IT reduced the hyperglycemia in diabetic rats by $21 \%$ compared with the DSE group (Table 2 ). This positive change in glycemic level might be explained by the modulation in different intracellular skeletal muscle signaling pathways, such as increase of GLUT-4 expression, which improves glucose uptake by insulinindependent pathways (22).

The IT protocol applied in this study, 30-s exercise with 30 -s rest, reduced plasma cholesterol and triacylglycerol levels in animals from IT and DIT group compared with their controls (Table 2). The improvement in muscle metabolism and attenuation of hyperglycemia with interval training may have been responsible for reductions in these parameters. Another possible mechanism involved in the reduction of plasma cholesterol and triacylglycerol blood levels by exercise is the contribution of the increased aerobic metabolism (23). The sum of stimuli, in which the recovery interval is insufficient to complete the resynthesis of creatine phosphate, enhances the contribution of aerobic metabolism and the use of lipids as energy source for exercise performance (6).

Neutrophils constitute the first line of defense against bacterial and fungal infections. Several studies have shown impairment of neutrophil function, a disorder that contributes to the high incidence of infections in diabetes (24). Interestingly, in our study, the functionality of neutrophils of DSE and DIT groups improved significantly (Table 3 ). Conflicting results have been reported about the production of $\mathrm{H}_{2} \mathrm{O}_{2}$ by neutrophils in diabetes. In unstimulated neutrophils from diabetic patients, no significant effect on $\mathrm{H}_{2} \mathrm{O}_{2}$ production was found $(25,26)$. Conversely, Zozulinska and cols. (27) encountered an increment in $\mathrm{H}_{2} \mathrm{O}_{2}$ production in diabetic patients. Among many possible factors responsible for the stimulation of functionality of neutrophils in diabetic rats, hyperglycemia seems to be the most important. It seems that the increased plasma glucose level may activate neutrophils by influencing intracellular carbohydrate metabolism. Wierusz-Wysocka and cols. (28) evaluated the functionality of neutrophils in fifteen patients with insulin-dependent diabetes mellitus and found increased superoxide onion production compared with the control group, corroborating our data.

Another important result of our study is that interval training did not alter the function of neutrophils. Some studies have shown that relatively short periods of intense training ( 1 to 3 weeks), may reduce the function of neutrophils $(29,30)$. The training protocol proposed in this study was characterized as predominantly anaerobic and high intensity. However, the IT and DIT groups did not alter the function of neutrophils compared to their respective controls, SE and DSE groups (Table 2). We infer that the divergence between our results and the previous reported studies may be related to the low volume of exercise characteristic of the training protocol applied by us. 
Interestingly, the interval training significantly improved functionality of peritoneal macrophages from IT compared with SE group (Table 4). Many studies have shown that moderate intensity exercises (> 65\% $\mathrm{VO}_{2 \max }$. have a positive effect in macrophage function and that high-intensity exercise, held for long periods of time can negatively alter the function of such cells (3133). Although recent studies have demonstrated that anaerobic exercise can improve immune function (34), there are still little information about type, intensity, duration, and recovery period of anaerobic exercise training program. To our knowledge, our study is the first to report the effects of chronic interval training on functionality of macrophages. As mentioned about neutrophils, the low training volume might be related to the absence of negative effects in the functions of the analyzed macrophages as well.

Our results also showed that functionality of peritoneal macrophages from the DSE and DIT group was increased (Table 4). As mentioned about neutrophils, hyperglycemia seems to be the most important factor to induce changes in the functionality of peritoneal macrophages.

The IT protocol applied in this study did not modify the lymphocyte proliferation index of trained rats (IT) when compared with non-trained ones (SE) (Figure 1). Our data corroborate findings of the literature that show that once immunity is acquired, it is not improved by physical activity. Longitudinal studies show that in the true resting state (i.e. more than $24 \mathrm{~h}$ of the last training session) the number of circulating lymphocyte and lymphocyte functions are similar in athletes and non-athletes (31).

It is believed that diabetics, especially those with poor control of disease, show deficiencies related to cell-mediated immunity. Therefore, there is less proliferative capacity of $\mathrm{T}$ lymphocytes in diabetics, but this suppression is not clearly understood and the results are inexpressive because of the complex interrelationships involved in cell-mediated immune response (35). Otto and cols. (36) discovered that the proliferation capacity of lymphocytes, in response to the mitogen concanavalin $\mathrm{A}$ (Con A) and lipopolysaccharide (LPS), decreased in diabetics rats compared with the control group. On the other hand, Miranda and cols. (37) showed that the proliferation of lymphocytes, in response to the mitogen concanavalin A (Con A), increased in diabetics rats compared with the non-diabetic control animals. In our study, the proliferation index of gut-associated lymphocytes from DSE compared with the SE group did not change. This difference in our study, compared with other studies, can be explained by distinctions between models of diabetes induction, periods of analysis, and their own technical assessment of proliferation.

Our research showed that the DIT group showed a twofold increased proliferation index compared with the DSE group (Figure 1). The diabetic condition of hyperglycemia can generate a pro-inflammatory environment that initially may contribute to activation of some cells, and chronically, can be cytotoxic and reduce functionality of immune cells, increasing susceptibility to infections. Therefore, the intensification of glycemic control will be able to improve the immune cells function in patients with type $1 \mathrm{DM}$. Our protocol of interval training increased lymphocyte proliferation of DIT group, and this positive change in glycemic level with exercise might be a feature important for the functionality of immune system cells in the diabetic condition. Our study is the first to report the positive effects of high intensity and low volume exercise on acquired immune system in the type $1 \mathrm{DM}$.

In summary, our data show that STZ-induced diabetes model resulted in increased functionality of blood neutrophils and peritoneal macrophages in the DSE group. Interval training attenuates hyperglycemia induced by type 1 diabetes, improves the lipid profile and induces changes in the functionality of the innate and acquired immunity. Another important feature of our study was the presentation of evidence revealing that low-volume high-intensity physical exercise is not prejudicial to immune cells functionality. The exploration of the variables intensity, duration, and recovery period may be an important additional strategy to achieve results with diabetic humans.

Disclosure: no potential conflict of interest relevant to this article was reported.

\section{REFERENCES}

1. Snowling NJ, Hopkins WG. Effects of different modes of exercise training on glucose control and risk factors for complications in type 2 diabetic patients. Diabetes Care. 2006;29:2518-27.

2. Admon G, Weinstein Y, Falk B, Weintrob N, Benzaquen H, Ofan R, et al. Exercise with and without an insulin pump among children and adolescents with type 1 diabetes mellitus. Pediatrics. 2005;116:348-55.

3. Bolue NG, Haddad E, Kenny GP, Wells GA, Sigal RJ. Effects of exercise on glycemic control and body mass in type 2 diabetes 
mellitus: a meta-analysis of controlled clinical trials. JAMA. 2001;286:1218-27.

4. Angelis $K$, Schaan BD, Maeda $C Y$, Dall'Ago P, Wichi RB, Irigoyen MC. Cardiovascular control in experimental diabetes. Braz J Med Biol Res. 2002;35:1091-100.

5. Kivelã R, Silvennoinem M, Touvra AM, Lehti TM, Kainulainen $H$, Vihko V. Effects of experimental type 1 diabetes and exercise training on angiogenic gene expression and capillarization in skeletal muscle. FASEB J. 2006;20:921-30.

6. Gibala MJ. High-intensity interval training: a time-efficient strategy for health promotion? Curr Sports Med Reports. 2007;6:211-3.

7. Burgomaster KA, Howarth KR, Phillips SM, Rakobowchuk M, MacDonald MJ, McGee SL, et al. Similar metabolic adaptations during exercise after low volume sprint interval and traditional endurance training in humans. J Physio. 2008;586:151-60.

8. Souza CF, Machado AF, Bonatto SJR, Grando FCC, Pessini C, Alves LE. Neutrophil response of anaerobic jump trained diabetic rats. Eur J Appl Physiol. 2008;104:1079-86.

9. Yamazaki RK, Hirabara SM,Tchaikovski OJ, Lopes MCP, Nogata C, Aikawa J, et al. The effects of peroxovanadate and peroxovanadyl on glucose metabolism in vivo and identification of signal transduction proteins involved in the mechanism of action in isolated soleus muscle. Mol Cell Biochem. 2005;273:145-50.

10. Braga LR, Mello MAR, Gobatto CA. Exercício contínuo e intermitente: efeitos do treinamento e do destreinamento sobre a gordura corporal de ratos obesos. ALAN. 2004;54:58-65.

11. Mcnaughton LR, Thompson D, Philips G, Backx K, Crickmore L. A comparison of the lactate Pro, Accusport, Analox GM7 and Kodak Ektachem lactate analysers in normal, hot and humid conditions. Int J Sports Med. 2002;23:130-5.

12. Togni V, Ota CC, Folador A, Junior OT, Aikawa J, Yamazaki RK, et al. Cancer cachexia and tumor growth reduction in Walker 256 tumor-bearing rats supplemented with $\omega 3$ polyunsaturated fatty acids for one generation. Nutr Cancer. 2003;46:52-8.

13. Bonatto SJR, Folador A, Aikawa J, Yamazaki RK, Pizatto N, Oliveira EHP, et al. Lifelong exposure to dietary fish oil alters macrophage responses in Walker 256 tumor bearing rats. Cell Immunol. 2004;231:56-62.

14. Pithon-Curi TC, Schumacher RI, Freitas JJS, Lagranha C, Newsholme P, Palanch AC, et al. Glutamine delays spontaneous apoptosis in neutrophils. Am J Physiol. 2003;284:1355-61.

15. Pizatto N, Bonatto S, Piconcelli M, Souza LM, Sassaki GL, Naliwaiko K, et al. Fish oil alters T-lymphocyte proliferation and macrophage responses in walker 256 tumor-bearing rats. Nutrition. 2006;22:425-32.

16. Licastro F, Davis LJ, Morini MC. Lectins and superantigens: membrane interaction of these compounds with T lymphocytes affect immune responses. Int J Biochen Cell Biol. 1993;25:845-52.

17. Babraj JA, Vollaard BDJ, Keast C, Guppy FM, Cottrell G, Timmons JA. Extremely short duration high intensity interval training substantially improves insulin action in young healthy males. BMC Endocrine Disorders. 2009;9:3.

18. American Diabetes Association. Standards of medical care in diabetes. Diabetes Care. 2008;31:12-54.

19. Johnston AP, Campbell JE, Found JG, Riddell MC, Hawke TJ. Streptozotocin induces G2 arrest in skeletal muscle myoblasts and impairs muscle growth in vivo. Am J Physiol Cell Physiol. 2007;292:1033-40.

20. Aragno M, Mastrocola R, Catalano MG, Brignardello E, Danni O, Boccuzzi G. Oxidative stress impairs skeletal muscle repair in diabetic rats. Diabetes. 2008;53:1082-88.
21. Krause MP, Riddell MC, Gordon CS, Imam SA, Cafarelli E, Hawke TJ. Diabetic myopathy differs between Ins2Akita+/- and streptozotocin-induced type 1 diabetic models. J Appl Physiol. 2009;106:1650-9.

22. Jessen N, Goodyear LJ. Contraction signaling to glucose transport in skeletal muscle. J Appl Physiol. 2005;99:330-7.

23. Talanian JL, Galloway SD, Heigenhauser GJ, Bonen A, Spriet LL. Two weeks of high-intensity aerobic interval training increases the capacity for fat oxidation during exercise in women. J Appl Physiol. 2007;102:1439-47.

24. Alba-LoureiroTC, Hirabara SM, Mendonça JR, Curi R, Pithon-Curi TC. Diabetes causes marked changes in function and metabolism of rat neutrophils. J Endocrinol Metab. 2006;188:295-303.

25. Inoue S, Lan Y, Muran J, Tsuji M. Reduced hydrogen peroxide production in neutrophils from patients with diabetes. Diabetes Res Clin Pract. 1996;33:119-27.

26. Noritake M, KatsuraY, Shinomiya N, Kanatani M, UwabeY, Nagata N. Intracellular hydrogen peroxide production by peripheral phagocytes from diabetic patients. Dissociation between polymorphonuclear leucocytes and monocytes. Clin Exp Immun. 1992;88:269-74.

27. Zozulinska DA, Wierusz-Wysocka B, Wysocki H, Majchrzak AE, Wykretowicz $A$. The influence of insulin-dependent diabetes mellitus (IDDM) duration on superoxide anion and hydrogen peroxide production by polymorphonuclear neutrophils. Diabetes Res Clin Pract. 1996;33:139-44.

28. Wierusz-Wysocka B, Wysocki $H$, Siekierka $H$, Wykretowicz A, Szczepanik A, Klimas R. Evidence of polymorphonuclear neutrophils (PMN) activation in patients with insulin-dependent diabetes mellitus. J Leuk Biol. 1987;42:519-23.

29. Lancaster Gl, Halson SL, Khan Q, Drysdale P, Wallace F, Jeukendrup $A E$, et al. The effects of acute exhaustive exercise and intensified training on type 1/type $2 \mathrm{~T}$ cell distribution and cytokine production. Exerc Immunol Rev. 2004;10:91-106.

30. Bury T, Marechal R, Mahieu P, Pirnay F. Immunological status of competitive football players during the training season. Int $\mathrm{J}$ Sports Med. 1998;19:364-8.

31. Nieman DC. Is infection risk linked to exercise workload? Med Sci Sports Exerc. 2000;32:406-11.

32. Smith LL, Anwar A, Fragen M, Rananto C, Johnson R, Holberte D. Cytokines and cell adhesion molecules associated with highintensity eccentric exercise. Eur J Appl Physiol. 2000;82:61-7.

33. Woods JA, Lu Q, Ceddia MA, Lowder T. Special feature for the Olympics: effects of exercise on the immune system: exerciseinduced modulation of macrophage function. Immunol Cell Biol. 2000;78:545-53.

34. Miles MP, Kraemer WJ, Nindl BC, Grove DS, Leach SK, Dohi K, et al. Strength, workload, anaerobic intensity and the immune response to resistance exercise in women. Acta Physiol Scand. 2003;178:155-63.

35. Liu C, Phil D, Chen K, Lee S, Tsai L. Effect of supplemental I-arginine on the function of T lymphocytes and the formation of advanced glycosylated end products in rats with streptozotocindiabetes induced. Nutrition. 2005;21:615-23.

36. Otto R, Carvalho CRO, Mendonça JR, Curi R. Low proliferation capacity of lymphocytes from alloxan-diabetic rats: involvement of high glucose and tyrosine phosphorylation of Shc and IRS-1. Life Sci. 2002;23:2759-71.

37. Miranda DTSZ, Batista VG, Grando FCC, Paula FM, Felício CA, Rubbo GFS, et al. Soy lecithin supplementation alters macrophage phagocytosis and lymphocyte response to concanavalin $A$ : a study in aloxan-induced diabetic rats. Cell Biochem Funct. 2008;26:859-65. 